RAFAEL ASSUMPÇÃO LAROCCA

\title{
MODULAÇÃO DA RESPOSTA IMUNE A ALOANTÍGENOS POR CÉLULAS TRONCO DERIVADAS DO TECIDO ADIPOSO
}

Tese apresentada ao Instituto de Ciências Biomédicas da Universidade de São Paulo, para obtenção do Título de Doutor em Ciências.

Área de concentração: Imunologia

Orientador: Niels Olsen Saraiva Camara

São Paulo

2009 


\section{RESUMO}

Larocca RA. Modulação da Resposta Imune a aloantígenos por Células-Tronco derivadas do tecido adiposo [Tese, Doutorado em Imunologia]. São Paulo: Instituto de Ciências Biomédicas da Universidade de São Paulo; 2009.

O sucesso dos transplantes de órgãos sólidos depende fundamentalmente do controle da resposta imune aos aloantígenos. Mesmo assim, a sobrevida de um enxerto não é definitiva. Portanto, a indução de tolerância imunológica em transplantes representa um ideal a ser alcançado. A identificação e caracterização de uma população de células reguladoras (Treg), as quais são capazes de controlar a resposta imune a aloantígenos, trouxeram uma nova perspectiva para a indução da tolerância imunológica em transplante. Essas células são geradas naturalmente no timo, em uma baixa freqüência e são identificadas principlamente pela expressão de marcadores como as moléculas CD25 e Foxp3. As Treg também podem ser expandidas ou até mesmo originadas na periferia, quando estimuladas pela presença de citocinas ou de populações especiais de células. Com base nestas informações, nós utilizamos células-tronco mesenquimais derivadas de tecido adiposo (ADSC), as quais possuem a capacidade de suprimir uma resposta imune no nosso modelo experimental. Assim, nossa proposta foi avaliar se as ADSC poderiam melhorar a sobrevida de um enxerto da cauda do doador alogenêico CBA/J em camundongos C57BL/6 e se esta melhora estaria associada à indução de Treg na periferia. Após $24 \mathrm{~h}$ os animais transplantados receberam ADSC do doador alogenêico $\mathrm{CBA} / \mathrm{J} 2 \times 10^{5}$ via intraperitoneal. Nos dias 3, 10 e no dia da rejeição os linfonodos drenantes e o enxerto foram removidos para análise do padrão de citocinas presentes e também a participação das Treg na resposta imune. Nós observamos que o tratamento com as ADSC levou a um aumento média da sobrevida do enxerto de 16,5 dias $(p=0,002)$, com uma melhora visível na morfologia do enxerto. Nos linfonodos dos animais tratados com as ADSC observamos um aumento na população de linfócitos T $\mathrm{CD}^{+} \mathrm{CD} 25^{+}{ }^{\mathrm{F}}{ }^{2} \mathrm{xp}^{+}{ }^{+}$nas primeiras 72 horas, com um aumento na expressão de IFN- $\gamma$ e IL10, no dia 10 após o transplante. A análise do enxerto nas primeiras 72 horas, mostrou uma inibição da expressão de IL-17 nos animais tratados com as ADSC, acompanhada de uma inibição na proliferação de células $\mathrm{T} \mathrm{CD}^{+}$, correlacionada com a baixa produção local de IFN- $\gamma$ e IL-17. Nossos achados sugerem que as ADSC suprimem a resposta imune ao enxerto, por meio da indução de Treg nas primeiras horas e inibe a participação das células Th17 neste processo, levando a uma melhora no enxerto. Estes dados ajudam a desenvolver novos aspectos na estratégia terapêutica e possivelmente o uso futuro dessas células na prática clínica.

Palavras-chave: Transplante de pele. Tolerância Imunológica. Células-tronco Mesenquimais. 


\section{SUMMARY}

Larocca RA. Modulation of Immune alloresponse by Adipose-tissue Derived Mesenchymal Stem Cells. [Thesis, PhD Immunology Program]. São Paulo: Instituto de Ciências Biomédicas da Universidade de São Paulo; 2009.

The success of solid organ transplantation is mainly due to control alloantigen immune response. Although, the current allogeneic graft survival is not definitive. Therefore, the induction of allograft tolerance is considered the Holy Grail in transplantation immunobiology. The identification and characterization of regulatory $\mathrm{T}$ cells (Treg) that can control immune responsiveness to alloantigens have opened up exciting opportunities for new therapies in Transplantation. These cells are naturally generated in the thymus and are at low frequency in normal conditions, being identified by the surface molecule markers such as CD25 and Foxp3. Treg cells can also be expanded and generated in the periphery, when stimulated with specific cytokines or special cell population. In this work, we believe that is possible to induce these cells in the periphery by stimulation with adipose-tissue derived mesenchymal stem cells, which have the capacity of suppressing the immune response. Then, we propose to study the role of ADSC cells in prolonging skin allograft survival, and whether this is associated with Treg cells induction in the periphery. C57Bl/6 mice were grafted with the skin tail from allogeneic donors (CBA/J). ADSC were isolated from CBA/J abdominal fat tissue and injected in recipients at 24 hours after engraftment. At 3 and 10 days after engraftment and at rejection time, the draining lymph-nodes and graft itself were studied. The cells from the draining lymph-nodes were analyzed by flow cytometry and IL-2, IL-6, IL-10, IFN- $\gamma$, IL-17 and Foxp3 mRNA were quantified in draining lymphnodes and in the graft. Graft survival was enhanced in animals that received ADSC from the skin donor $(16,5 ; \mathrm{P}=0,002)$. Interestingly, ADSC-treated animals presented a higher expression of Foxp3 $3^{+}$cells in the $\mathrm{CD}^{+} \mathrm{CD}^{2} 5^{+} \mathrm{T}$ cell population in the lymphnodes at $72 \mathrm{hr}$ with an enhancement in IFN-g and IL-10 mRNA expression after surgery. In ADSC-treated mice we also noticed a low expression of IL-17 /in vivo /at 72 hs. Moreover, /in vitro/ analyses showed a capacity of ADSC in inhibiting T CD4 ${ }^{+}$cells proliferation, and this suppression was accompanied by decreased levels of IFN- $\gamma$ and Il-17. Our data suggest that ADSC suppress the allogeneic immune response with early induction of Treg population cells and inhibit Th17 cells, prolonging longer skin graft survival. These data open news perspectives for therapeutic use in clinical setting.

keywords: Transplantation. Immunological Tolerance. Mesenchymal Stem Cells. 


\section{INTRODUÇÃO}

\subsection{Histórico}

A imunologia dos transplantes iniciou em meados da década de 40 quando o biólogo britânico Peter Medawar juntamente com seu colega cirurgião plástico Thomas Gibson em 1943 descreveram sua primeira experiência com transplante de pele. Durante a segunda guerra mundial, os casos de queimaduras eram constantes, e devido à extensão das áreas lesionadas, fazia-se necessário a busca por doadores de tecidos. Sucintamente, os pesquisadores removeram pequenas partes de tecido da própria paciente para colocar nas áreas queimadas, chamados de transplantes autólogos, e junto a esses enxertos foram adicionados partes de pele de seu irmão, um transplante homólogo. Ao avaliarem o aspecto dos enxertos, eles notaram que os enxertos provenientes da mulher estavam aderidos e permaneceram com aspecto saudável, enquanto os enxertos provenientes do irmão apresentavam uma degeneração tecidual por volta de 15 dias, sendo totalmente rejeitados com 23 dias. Os pesquisadores ficaram intrigados e realizaram um segundo set de transplantes com a pele proveniente do irmão, e perceberam uma rejeição acelerada (8 dias pós transplante), o que eles chamaram de imunização ativa [1].

No entanto, Medawar imediatamente tratou de repetir essas observações em grande escala em coelhos, onde detalhou mudanças histológicas, e seus resultados foram descritos em dois artigos. O primeiro, publicado em 1944, contém uma detalhada descrição da morfologia e histologia do enxerto, com a presença de um intenso infiltrado inflamatório de linfócitos e monócitos [2]. Em seu segundo estudo, ele confirmou suas observações anteriores, principalmente com os experimentos de retransplante, e concluiu que o tempo de sobrevida do enxerto é determinado pela 
expressão de antígenos nos doadores e receptores, postulando as Leis do Transplante e estabelecendo uma íntima relação entre a rejeição de transplantes e o sistema imune [3].

O sistema imune é classicamente dividido em dois compartimentos: o inato que compreende os monócitos, macrófagos, neutrófilos, eosinófilos, mastócitos e as células matadoras naturais NK (do inglês, Natural Killer) e componentes solúveis como o sistema complemento, e o adaptativo que envolve ativação de linfócitos B e T antígenos-específicos. Durante um longo período, atribuiu-se ao sistema imune adaptativo a responsabilidade de gerar respostas específicas que levariam a rejeição ou a tolerância de um órgão transplantado e que o compartimento inato seria apenas a uma linha de defesa contra microrganismos. Entretanto, esse tipo de visão vem sendo questionada e atualmente há trabalhos que demonstram a importância do sistema imune inato e também de danos não-específicos na rejeição [4].

Com o descobrimento dos receptores do tipo Toll (TLR; do inglês Toll like receptors), ficou evidente a interação entre o sistema imune inato e adaptativo [5]. Tendo em vista que a ativação do sistema imune adaptativo depende não somente da apresentação de antígenos dependente do complexo principal de histocompatibilidade (MHC; do inglês, Major histocompatibility complex), mas também da indução de moléculas acessórias nas células apresentadoras de antígenos (APC; do inglês, Antigen presenting cells), [6] criou a hipótese de que TLR expressos nas APC poderiam regular os sinais acessórios (co-estimulação e citocinas) e, conseqüentemente, controlar a ativação de respostas adaptativas antígeno-específicas. Essa descoberta ajudou a compreendermos melhor os mecanismos envolvidos no processo de rejeição a um órgão sólido. 


\subsection{Imunologia da Rejeição}

A rejeição pode ser entendida como a deterioração funcional e estrutural do enxerto, e que podem ser mediada por anticorpos e/ou por células. Antigamente os mecanismos de rejeição eram classificados de maneira generalizada aplicando-se a todos os tipos de transplantes denominados como: rejeição hiperaguda, rejeição celular aguda, rejeição humoral aguda e rejeição crônica. De acordo com os critérios adotados pelo consenso bianual (BANFF) realizado em 2007 no Canadá, a terminologia atual foi classificada como: rejeição mediada por anticorpos (aguda e crônica) e rejeição mediada por células T (aguda e crônica) [7]. Muito embora esses critérios tenham sido criados com base nos achados histológicos renais, podemos abranger para os outros tipos de transplante.

A rejeição aguda mediada por anticorpos é caracterizada por uma perda precoce do enxerto, normalmente nas primeiras 48 horas. Ela ocorre quando há anticorpos préformados presentes na circulação do receptor, com especificidade para antígenos expressos nas células do enxerto. Tais anticorpos (Ac) são classificados: Ac de baixa afinidade como imunoglobulina $M(\operatorname{IgM})$, que são específicos para os antígenos $A B O$, entre outros, e IgG de alta afinidade dirigidos contra os antígenos do MHC. Não se sabe ao certo como e por que esses anticorpos são formados, acredita-se que seja através de contatos prévios com o antígeno ou alguns microrganismos que mimetizem essas moléculas antigênicas. A ligação destes anticorpos nas células-alvo desencadeia a ativação da cascata de coagulação, sistema complemento e cascata das cininas levando a trombose, isquemia e necrose do tecido. A rejeição crônica mediada por anticorpos é mais tardia podendo levar de meses a anos para se estabelecer, e é caracterizada pela deposição da molécula do sistema complemento $\mathrm{C} 4 \mathrm{~d}$, mas segundo as normas da BANFF para ser considerado como rejeição crônica o tecido deve apresentar, intensa fibrose intersticial, atrofia tubular e mudanças vasculares [8]. 
A rejeição aguda mediada por células é caracterizada pelo intenso infiltrado celular composto de células mononucleares como macrófagos e principalmente linfócitos $\mathrm{T} \mathrm{CD}^{+}$e $\mathrm{T} \mathrm{CD}^{+}$o que leva a lesão tecidual e subseqüente necrose. $\mathrm{O}$ que diferencia a fase aguda da crônica é a formação de fibrose devido aos produtos produzidos pelos macrófagos o que leva a perda da função do órgão ou tecido [9].

Os aloantígenos desencadeiam tanto respostas imunes celulares como humorais. Os genes polimórficos expressos codominantemente influenciam, entre outros fatores, o modo como o sistema imune do receptor irá responder ao enxerto. As principais moléculas responsáveis por desencadear a rejeição de órgãos são as moléculas do MHC, altamente polimórficas e expressas em praticamente todos os tecidos e células nucleadas. As moléculas de MHC alogenêicas são reconhecidas classicamente pelas células T do indivíduo transplantado por 3 vias. A primeira é a via direta, que envolve o reconhecimento por linfócitos $\mathrm{T}$ do receptor, de moléculas de MHC intactas exibidas na superfície das APC do doador. Na via indireta, os linfócitos T do receptor reconhecem peptídeos derivados de moléculas de MHC alogenêicas e proteínas da degradação de células do enxerto, que são capturadas, processadas e apresentadas dentro de moléculas de MHC próprias, no contexto da APC do indivíduo transplantado. Os aloantígenos processados podem ser apresentados tanto por MHC classe I como MHC classe II e ativam células $\mathrm{T} \mathrm{CD}^{+}$e $\mathrm{T} \mathrm{CD} 4^{+}$, respectivamente [10]. Recentemente, foi evidenciado a via semi-direta, onde moléculas da superfície celular como o MHC, podem ser transferidas das células do doador para as células do receptor. Assim as células próprias apresentariam antígenos do doador num contexto de MHC alogenêico resultando numa resposta imune ao enxerto [11]. Tem se descrito dois mecanismos de atuação na via semi-direta, o contato célula-célula [12] ou a captação vesículas exossomais [13].

Fica evidente que neste processo estão envolvidos tanto o compartimento inato quanto o adquirido do sistema imune, como demonstrado que a ativação via TLR leva a 
um aumento na expressão de moléculas de MHC nas células dendríticas DC, assim como aumento nas moléculas co-estimuladoras CD80, CD86 e CD40 levando a uma melhor ativação do compartimento de células T [14]. Devido a essa íntima ligação entre os antígenos de $\mathrm{MHC}$ e a rejeição, não há dúvidas de que as células $\mathrm{T}$ tenham uma participação fundamental nesse processo, assim é fato importante um melhor conhecimento dessa população celular.

\subsection{Caracterização das sub-populações de linfócitos T}

Em um estudo clássico da década de 80, Mosmann e colaboradores descreveram que células $\mathrm{T} \mathrm{CD4}^{+}$podiam ser subdivididas funcionalmente em dois grupos: aquelas que secretam interferon gama (IFN- $\gamma$ ) e aquelas que secretam interleucina 4 (IL-4). Com base nesses dados foi concluído que as células T $\mathrm{CD}^{+}$não eram um grupo homogêneo, mas apresentavam diversas populações supostamente distintas [15].

As primeiras descrições de diferenciação celular de linfócitos $\mathrm{T}$, in vitro, foram relatadas em 1990. Primeiramente, foram descritos estudos nos quais células T naives não produziam IL-4, porém, quando estimuladas pelo receptor de células T (TCR, do inglês $T$ cell receptor) na presença de IL-4, essas células podiam se tornar grandes produtoras dessa citocina [16, 17]. Em seguida, foi observado que para que ocorresse essa diferenciação, in vitro, era necessária a ativação de uma via de sinalização que incluía o receptor de IL-4, a proteína STAT-6 (fator transdutor de sinal e ativador da transcrição, do inglês, signal transducer and activator of transcription) e o fator de transcrição GATA-3 [18, 19].

Essa dicotomia entre a diferenciação de células T CD4+ auxiliares (células Th, do inglês Thelper cells) para um padrão Th2 por meio da ação de IL-4 e da diferenciação de células para Th1 por meio da ação da IL-12 parecia elucidada. Contudo, essa diferenciação foi se mostrando não ser tão simples. Foi observado que a IL-12 induz 
uma produção de IFN- $\gamma$, mediada pela expressão do fator de transcrição T-bet, levando a um aumento significativo na produção de IFN- $\gamma$. Viu-se que o IFN- $\gamma$ atua como um mecanismo de feedback positivo para a célula e que a sua neutralização diminui a diferenciação de células para um padrão Th1 [20, 21].

A resposta imune a transplantes era vinculada até recentemente a uma predominância do compartimento Th1 onde células $\mathrm{T}$ efetoras, geradas após a apresentação dos aloantígenos migram para o local do transplante. Uma vez infiltradas no enxerto, as células antígeno-específicas geram uma resposta inflamatória local que resulta em subseqüente aumento da migração de células não específicas ao tecido, acarretando na destruição do tecido alogenêico transplantado [22]. Takiishi e colegas demonstraram a presença de um grande infiltrado de células $\mathrm{T} \mathrm{CD} 4^{+}$e $\mathrm{CD} 8^{+}$no sétimo e nono dia pós-transplante, sendo que o influxo de células $\mathrm{T} \mathrm{CD} 4^{+}$era predominante. A autora sugere que exista uma grande colaboração entre os dois tipos celulares e que as células $\mathrm{T} \mathrm{CD}^{+}$devido à produção de citocinas seja um importante fator no processo de rejeição do tecido (dados não publicados) [23].

Alguns trabalhos sugerem que a presença de células $\mathrm{T} \mathrm{CD} 4^{+}$seria fundamental para rejeição de enxertos alogenêicos $[24,25]$, enquanto outro indica que células T CD8 ${ }^{+}$ são capazes de mediar rejeição sem presença de células T CD4+ [26]. Trabalhos mostram que a participação de células T $\mathrm{CD} 4^{+}$é maior quando existe disparidade no $\mathrm{MHC}$ de classe II entre o receptor e o doador, enquanto que as células T CD8 ${ }^{+}$participariam da rejeição mediada por disparidade no MHC classe I. Esses trabalhos sugeriram que a participação de ambos os tipos celulares são importantes para o processo de rejeição $[27,28]$. Hoje sabemos que os antígenos podem ser apresentados tanto para células $\mathrm{T}$ $\mathrm{CD}^{+}$quanto $\mathrm{T} \mathrm{CD}^{+}$, devido a um fenômeno que conhecemos como apresentação cruzada, onde antígenos citoplasmáticos que seriam apresentados via MHC de classe I para células T CD8 ${ }^{+}$, sejam apresentados pelo MHC de classe II para células T CD4+ ou 
que antígenos endossomais seriam apresentados num contexto de MHC de classe I para células T CD8+ [29]. Em 2004, Youssef e colegas mostraram que a participação de células $\mathrm{T} \mathrm{CD} 4^{+}$ou $\mathrm{T} \mathrm{CD}^{+}$depende do tecido transplantado e do grau de disparidade antigênica. A pele é rejeitada tanto por células $\mathrm{T} \mathrm{CD}^{+}{ }^{+}$como $\mathrm{T} \mathrm{CD}^{+}$em qualquer grau de incompatibilidade genética, porém na ausência de células $\mathrm{T} \mathrm{CD}^{+}$, o enxerto apresentava um aumento na sobrevida [30].

Outros dois tipos de células T descritos na resposta imune aos transplantes são as células $\mathrm{T}$ reguladoras (papel protetor) e as células Th17 (papel efetor). No microambiente do enxerto apesar da característica supressora do fator transformador $\beta$ (TGF- $\beta$, do inglês Transforming growth factor $\beta$ ) e de sua importância na geração de células $\mathrm{T}$ reguladoras, este, em conjunto com IL-6, induz a diferenciação de células T $\mathrm{CD}^{+}$numa subpopulação de linfócitos $\mathrm{T}$ produtores de IL-17, que apresenta um importante papel no processo inflamatório [31]. Essas células denominadas de Th17 expressam o fator de transcrição ROR $\gamma \mathrm{T}$ (do inglês, Related Orphan Receptor $\gamma$ ) e inibem a indução do fator de transcrição Foxp3 (do inglês, Forkhead Box P3) nas células reguladoras induzida por TGF- $\beta$ na presença de IL-6 [32]. Essas células são inibidas pelas citocinas IFN- $\gamma$, IL-2, IL-4, IL10 e IL-27, secretadas por células Th1 e Th2 e atuam como mediadoras do recrutamento de neutrófilos para os sítios de inflamação [33, 34].

As células Th17, também são dependentes de IL-23 para sua sobrevivência e manutenção [33, 34]. Apesar de alguns pesquisadores apontarem a IL-23 como um fator importante apenas para a expansão de células Th17 (Afzali et al., 2007), foi mostrado que a IL-23 é necessária para promover um fenótipo patogênico às células Th17, confirmando os estudos iniciais sobre a função indispensável de IL-23 nos modelos de doenças auto-imunes induzidas por células Th17. A via de sinalização STAT3/IL-6 é importante para o desenvolvimento de células Th17 [35]. 
A descoberta das células Th17 levou a quebra da teoria em que a resposta imune era ditada por um balanço entre as células Th1/Th2. Isso elucidou uma série de mecanismos antes desconhecidos, mas abriu uma série de novas perguntas.

A citocina IL-27, uma citocina que está relacionada com a inibição de células Th17, é capaz de induzir a produção de IL-10. A IL-10 foi originalmente descrita como um produto de células Th2, mas é produzida por uma diversidade maior de células [36, 37], entre elas, subtipos de células T reguladoras [38]. A produção de IL-10 é aumentada em células T CD4 ${ }^{+}$estimuladas com IL-27 in vitro. Quando a IL-27 é adicionada à cultura de linfócitos $\mathrm{T}$ polarizada para o perfil Th17, na presença de TGF- $\beta$ e IL-6, a IL-27 efetivamente bloqueia a produção de IL-17, mas não a produção de IL-10 [39].

Awashi e colaboradores descreveram outra via de produção de IL-10, tanto in vitro como in vivo [40]. Eles descobriram que a exposição de células dendríticas a células $\mathrm{T}$ reguladoras induzidas promovia a diferenciação dessas células com características plasmocitóides, possuidoras de uma maior capacidade tolerogênica. Essas células dendríticas plasmocitóides induzem células $\mathrm{T}$ naives a se diferenciarem em células $\mathrm{T}$ supressoras produtoras de IL-10. Dentre os fatores solúveis produzidos pelas células dendríticas plasmocitóides encontram-se a IL-27 e o TGF- $\beta$ que, em conjunto, induzem à produção de IL-10. Esses autores também usaram camundongos deficientes do receptor de IL-27 e observaram que a IL-27 produzida pelas células dendríticas plasmocitóides é necessária para a produção de IL-10. As células T cultivadas com as células dendríticas plasmocitóides possuem as características de células T reguladoras do tipo 1, uma vez que produzem tanto IL-10 e IFN- $\gamma$, expressam o fator de transcrição T-bet e não expressam os fatores de transcrição GATA-3, Foxp3 e ROR $\gamma \mathrm{T}$ [41].

O papel das células Th17 no processo de rejeição do enxerto ainda não foi bem avaliado. Contudo, seus papéis em modelos de doenças auto-imunes foram descritos. 
Foi observado que células $\mathrm{T} \mathrm{CD}^{+}$de camundongos imunizados com peptídeos indutores de EAE (do inglês, Experimental Autoimmune Encephalomyelitis), quando reestimuladas, in vitro, na presença de IL-23 são capazes de transferir EAE, in vivo. As mesmas células, agora re-estimuladas na presença de TGF- $\beta$ e IL-6, além de não serem patogênicas, eram capazes de prevenir a indução de EAE dependentemente de IL-10, quando transferidas em conjunto com células T patogênicas.

Assim o processo de rejeição é mediado pelo sistema imune, se fazendo necessário uso de mecanismos supressores, como drogas, que quase sempre são tóxicas ao organismo, ou então mecanismos de indução de tolerância.

\subsection{Tolerância Imunológica}

A tolerância imunológica pode ser definida como um processo de homeostase do organismo no qual é mantido um estado de anergia a tecidos próprios e ocorre tanto no timo (tolerância central) quanto na periferia (tolerância periférica). No timo, os timócitos cujos TCR se ligam com intensidade moderada a antígenos próprios sobrevivem e migram para os órgãos periféricos [42]. Quando se ligam fortemente aos antígenos próprios sofrem apoptose através da morte celular induzida por ativação ou, ainda, morrem por negligência por não se ligarem a antígeno algum (morte celular passiva). Um fator de transcrição presente no timo tem ganhado grande destaque no processo de seleção tímica por regular a transcrição de genes tecido específicos [43]. Esse fator de transcrição foi denominado AIRE (regulador da auto-imunidade, do inglês, autoimmune regulator) e mutações no gene codificador de AIRE induz o desenvolvimento de doenças auto-imunes, indicando que a sua ação na expressão de genes tecidos específico é fundamental no processo de tolerância central [43, 44]. Contudo, a tolerância central não elimina totalmente os linfócitos autorreativos, já que clones autorreativos são comumente encontrados na periferia do organismo de indivíduos sadios [45-47] e 
mecanismos de regulação periféricos existem controlando a autorreatividade potencialmente patológica.

A tolerância periférica ocorre por diferentes mecanismos que atuam em conjunto ou individualmente, sendo eles: (i) anergia (incapacidade de ativação e proliferação, desenvolvida ao se reconhecer um antígeno sem co-estimulação adequada) [48]; (ii) o reconhecimento de receptores inibitórios como o CTLA-4 (do inglês, Cytotoxic $T$ Lymphocyte Antigen-4) que se liga à molécula CD28 e inibe a produção de IL-2, levando à conseqüente apoptose do linfócito [49, 50]; (iii) apoptose devido à estimulação antigênica repetida dos linfócitos T [51]; (iv) ignorância das células T (quando estas células não encontram antígenos para se ligarem) [52]; (v) indução de tolerância por células $\mathrm{T}$ reguladoras [53-55] e (vi) mudança no perfil de citocinas produzidas, alterando o perfil da resposta imune $[56,57]$.

\subsection{Células $\mathrm{T}$ reguladoras}

As células com papel regulador têm sido alvo de muitas pesquisas ao longo dos anos. Uma das primeiras pesquisas, descritas por Gershon e Kondo com este tema surgiu na década de 70, então denominadas de células supressoras. Porém, foi somente a partir dos anos 90 que a existência destas células passou a ter uma aceitação maior por parte dos pesquisadores [58].

Os diversos mecanismos responsáveis pela manutenção da homeostase imunológica têm despertado interesse da comunidade científica. Umas variedades de células têm sido descritas por apresentarem uma atividade reguladora, dentre elas, as células NKT (do inglês, Natural Killer T cell) [59] e NK [60], células CD8+ [61], CD8+CD28- [62], CD8 ${ }^{+} \mathrm{CD}^{+} 5^{+}$[63] $\mathrm{CD}^{+}{ }^{+} \mathrm{CD} 25^{-}$[64] e células $\mathrm{T} \gamma \delta[65,66]$. Groux e colaboradores descreveram que células T específicas a um antígeno têm a capacidade de suprimir a proliferação de células $\mathrm{T} \mathrm{CD}^{+}$, em resposta a um determinado antígeno, 
prevenindo a ocorrência de colite auto-imune em camundongos SCID (modelo de imunodeficiência severa combinada de camundongos; do inglês, Severe combined immunodeficiency). Essas células caracterizadas pela alta produção de IL-10, foram chamadas de células T reguladoras tipo 1 (Tr-1) [67].

Em 1994, Chen e colaboradores descreveram outro tipo de célula $\mathrm{T}$ com característica reguladora, células Th3, capazes de inibir a proliferação de clones de células T por meio de alta produção de TGF- $\beta$ [68]. Em 1995, Sakaguchi e colaboradores identificaram um terceiro tipo de células $\mathrm{T} \mathrm{CD}^{+}$reguladoras as quais expressavam a cadeia $\alpha$ do receptor de IL-2, com capacidade de controlar células T auto-reativas in vitro e in vivo. Esses estudos resultaram na identificação de uma população de células T com capacidade suprimir e ou regular, outras populações celulares sendo denominadas nessa época, de células T CD4+CD25+.

As células $\mathrm{T} C \mathrm{CD} 4^{+} \mathrm{CD} 25^{+}$originam-se no timo e são conhecidas como células reguladoras naturais e constituem cerca de $5-10 \%$ de todas as células $\mathrm{T}$, no sistema murino, exibindo uma potente atividade reguladora tanto in vivo como in vitro (Sakaguchi et al,1995). Essas células T reguladoras suprimem a proliferação de células T CD4 ${ }^{+} \mathrm{CD} 25-$ e células T CD8 ${ }^{+}$, assim como a secreção de IFN- $\gamma$, tanto in vitro como in vivo [69]. Células similares também foram encontradas em humanos [70]. Essas células desempenham um importante papel na regulação da resposta imune através da inibição de células T auto-reativas. Mais recentemente, foi identificada nessas células uma alta expressão do fator de transcrição chamado Foxp3 [71]. O Foxp3 é um fator da proteína escurfina pertencendo à família de fatores de transcrição forkhead [72]. A regulação de sua expressão e sua importância dentro da população de células T reguladoras serão descritos posteriormente. 
A expressão de Foxp3 em células $\mathrm{T}$ de camundongos é considerada um bom marcador das células $\mathrm{T}$ reguladoras, contudo, em humanos, Foxp3 pode ser induzido transitoriamente em células $\mathrm{T}$ ativadas, não sendo um marcador específico do estado de regulação, diferentemente do que é observado em camundongos [73, 74]. Assim, apesar de ser importante para a função supressora das células T reguladoras, o Foxp3 pode ser induzido em células T ativadas via TCR [75]. Além disso, em humanos, alguns tipos de células T reguladoras que não expressam Foxp3 foram relatados [37].

A manutenção e sobrevivência das células T $C D 4^{+} \mathrm{CD} 25^{+}$é regulada por IL-2. O uso de anticorpos anti-IL-2 anula completamente a função supressora das células $\mathrm{CD}^{+}{ }^{+} \mathrm{CD} 25^{+}$, in vitro [76]. Esses autores também demonstraram que a neutralização de IL-2, in vivo, inibe a proliferação homeostática de células $\mathrm{T} \mathrm{CD} 4^{+} \mathrm{CD} 25^{+}$periféricas em animais linfopênicos. A importância de IL-2 na geração e expressão de Foxp3 no timo também tem sido investigada. Contudo, alguns resultados contrastantes não permitem estabelecer um papel da IL-2 na ontogenia das células T reguladoras naturais. Fontenot e colaboradores não encontraram uma relação entre a expressão de Foxp3 em timócitos e sinais mediados pela IL-2 [77]. Em contraste a esse trabalho, foi mostrado, posteriormente, que a interação da IL-2 com o seu receptor parece ser essencial, no timo, para promover a geração de células T reguladoras e regulação da expressão de CD25 e Foxp3 [78]. Assim, não se consegue estabelecer precisamente qual o papel da IL-2 na geração células $\mathrm{T} C D 4^{+} \mathrm{CD} 25^{+}$, mas sim sua importância para a manutenção dessas células na periferia.

Diversas moléculas de superfície foram identificadas e associadas com células $\mathrm{T}$ reguladoras murinas e humanas, como o CTLA-4 [79], neutropilina-1 [80], LAG-3 (do inglês: Lymphocyte activation gene-3) [81] GITR (do inglês: Glucocorticoid Induced Tumor Necrosis Factor Family-Releted Receptor) [82], receptores de quimiocinas CCR4 e CCR8 
[83], L-selectina [84]. Algumas destas moléculas têm se mostrado importante na função supressora das células T reguladoras no sistema murino.

As células $\mathrm{T}$ reguladoras podem atuar suprimindo a resposta imune tanto por meio de fatores solúveis como TGF- $\beta$ e IL-10 quanto por um mecanismo dependente de contato célula a célula, como mediados pelo CTLA-4 [85-87]. Novos mecanismos de supressão mediados pelas células $\mathrm{T}$ reguladoras têm surgido. Recentemente, foi descrito uma forma de supressão mediada pelas células $\mathrm{T}$ reguladoras que se baseia na capacidade dessas células consumirem os fatores de crescimento presentes no microambiente, como a IL-2, privando as células efetoras desses fatores. A depleção de IL-2 realizada pelas células $\mathrm{T}$ reguladoras induz as células efetoras a entrarem em apoptose [88]. As células $\mathrm{T}$ reguladoras possuem uma maior quantidade de receptores de alta afinidade para IL-2 o que as dá uma vantagem competitiva com outras células do sistema imune, além de fornecer um mecanismo de supressão adicional, a secreção de IL-10 induzida por IL-2 [89]. Estudos realizados em camundongos perforina ${ }^{--}$, que possuem defeitos nos mecanismos de imunorregulação, sugerem que a granzima B possa atuar mediando à supressão via um mecanismo perforina-independente e contato-dependente, embora não se saiba como a granzima B atuaria na ausência de perforina [90]. Outro mecanismo de supressão descrito é mediado pelo cAMP (do inglês, cyclic adenosine monophosphate). Nesse modelo de supressão contato-dependente, células T reguladoras têm altas concentrações de cAMP e, por meio de junções do tipo Gap, o cAMP presente nas células $\mathrm{T}$ reguladoras é transportado a outra célula, suprimindo sua resposta [91]. O mecanismo pelo qual o cAMP age ainda não é completamente conhecido, mas parece estar relacionado com a inibição da produção de IL-2 mediada pela ICER (do inglês: cAMP inducible early repressor) [92-94].

O metabolismo de adenosina também foi relatado num processo de supressão mediado pelas células T reguladoras. A regulação do catabolismo extracelular de ATP, 
pelas células $\mathrm{T}$ reguladoras, leva à geração de adenosina. $\mathrm{O}$ passo inicial é realizado pelo CD39 que quebra ATP em ADP e ADP em AMP. O AMP é rapidamente degradado a nucleotídeo pelo CD73. A adenosina gera seus efeitos supressores ao se ligar em receptores purinérgicos acoplados à proteína $G$, presente em células $T$, $o$ receptor A2A [95]. Outros mecanismos de supressão também foram descritos, como na geração de células $\mathrm{T}$ reguladoras gerenciado por células dendríticas plasmocitóides expressando IDO (do inglês, Indoleamine-pyrrole 2,3-dioxygenase). Essas células T reguladoras estimulariam a expressão de PD-L em outras células dendríticas que ao se ligarem a PD-1 (do inglês, Programmed Death 1), presente em células T efetoras, induziria apoptose nessa população [96]. Como pode ser observado pela grande variedade de mecanismos supressores, diversos são os caminhos para a tolerância e imunorregulação. É provável que diferentes indivíduos possuam mecanismos singulares de regulação que os conduzem a diferentes desfechos dos diversos processos imunológicos. A compreensão mais global desses mecanismos pode gerar conhecimentos para que as intervenções clínicas sejam mais eficazes.

O potencial terapêutico dessas células em prevenir a rejeição de transplantes tem sido de grande interesse. Essas células podem ser manipuladas e geradas in vitro, desta forma poderiam ser infundidas nos receptores de transplante, assim aumentando a sobrevivência do tecido enxertado [97].

\subsection{Células-tronco}

As células-tronco (CT) são definidas como uma população de células com capacidade de permanecer em um estágio indiferenciado e que ao gerar células filhas, tem como características gerar células idênticas. Toda vez que uma célula não tronco se divide por mitose, ela da origem a duas células filhas semelhantes a ela. Em um processo de divisão assimétrica, como ocorre com as CT, tem-se uma separação 
citoplasmática diferenciada gerando uma célula idêntica a original, que se expandirá clonogenicamente, e outra célula progenitora comprometida com uma linhagem específica. A divisão assimétrica também ocorre no desenvolvimento do zigoto, em suas primeiras divisões, e na espermatogênese e oogênese [98].

Outra definição importante para as CT é relacionada à sua origem, como célulastronco embrionárias (CTE) e células-tronco adultas (CTA). Existem diferenças entre as CTE e CTA. A principal diferença é no conceito de potencialidade. Define-se potencialidade como a capacidade das CT em gerar células filhas diferentes, de acordo com o folheto germinativo. Em princípio, as CTE possuem maior potencialidade que as CTA, pois conseguem originar células filhas dos três folhetos germinativos.

Sendo assim as células se classificam como: totipotentes - são as CT com capacidade dar origem a um novo organismo, como é o caso de células do zigoto; pluripotentes - células que podem dar origem a células dos três folhetos germinativos; multipotentes - células que já possuem certo grau de especialização, que as permite apenas gerar células de um folheto germinativo, como as CTA mesenquimais da medula óssea e unipotente ou progenitora - células que podem produzir um único tipo celular que mantêm a capacidade de auto-replicação, o que a distingue de uma célula não tronco, como as CTA residentes em órgãos [99].

\subsection{Células-tronco adultas}

Pela definição de CT (auto-renovação e potencialidade), podemos encontrá-las em todos os órgãos. Mais do que se diferenciar, as CTA são responsáveis pela manutenção da homeostase e integridade do tecido. As CTA são definidas como CT multipotentes, ou seja, que ao se dividirem podem dar origem a células de apenas um folheto germinativo, ou seja, se a CTA estiver no cérebro, ela dividirá e dará apenas origem a células da ectoderme. As CTA são encontradas em diversos tecidos, tais como 
medula óssea, tecido adiposo, fígado, rim, placenta, cordão umbilical, entre outros [100].

Em um tecido, as CTA localizam-se em determinadas regiões chamadas de nichos [101]. Os nichos são regiões específicas nas quais as CTA se mantêm em estado quiescente. Durante o desenvolvimento humano, as CT se estabelecem nesses nichos, que as sustentam e que as regulam quanto à proliferação. As outras células presentes no nicho geram um abrigo para as CT impedindo que elas sofram diferenciação, estímulos apoptóticos ou qualquer outro estímulo que as levem a diferenciação. Além disso, o nicho previne a excessiva produção de $\mathrm{CT}$, que poderia resultar na formação de tumores [101, 102].

Sugere-se que o papel das CTA seja de regeneração [103]. No caso de uma lesão, as CTA que se encontram quiescentes em seus nichos, recebem sinais do meio ambiente que induzem sua ativação, divisão e migração para o local lesado. Isso ocorre devido à liberação de quimiocinas que atrai essas células para região lesada.

Alguns mecanismos de ação regenerativas das CTA incluem: a transdiferenciação - uma vez que a célula é indiferenciada e que pode dar origem a outras células, pode-se sugerir que ao encontrar a célula lesada ela se diferencie para repor essa célula que está morrendo. Entretanto esse mecanismo é muito complexo e pouco sugestivo, uma vez que já se pode observar melhora funcional em muitos modelos experimentais em 24 horas, que é um tempo muito curto para a CTA se diferenciar; a fusão - alguns autores sugerem que as CTA possam se fundir a célula que está morrendo e então auxiliar no reparo. Diversos estudos, entretanto, encontram poucas CTA no tecido lesado, analisados por diversas técnicas; e o parácrino - CTA no tecido lesado são ativadas pelos estímulos inflamatórios e secretam diversos fatores tróficos que podem não só auxiliar a célula que está morrendo como podem também estimular a CT no local [104]. 
Atualmente se acredita que o papel parácrino da CTA seja o principal mecanismo de ação. Diversas são as substâncias secretadas pelas CTA que seriam as responsáveis por suas ações regenerativas, anti-inflamatórias e anti-apoptóticas [105107]. Dentre as CTA mais estudadas temos as CT oriundas da medula óssea: as célulastronco hematopoiéticas (CTH) e as células-tronco estromais da medula óssea (CTM).

\subsection{Células-tronco Mesenquimais (CTM)}

As CTM são células-tronco clonogênicas e não hematopoiéticas, presentes na medula óssea e são capazes de diferenciar-se em múltiplas linhagens celulares do tipo mesoderma como, por exemplo, osteoblastos, condrócitos, células endoteliais assim como diversas células do tipo não-mesoderma como células neuronais. Já existem métodos para isolar as CTM. Eles se baseiam em características físico-químicas, como por exemplo, a aderência a plásticos ou a outros componentes da matriz extracelular. Devido ao seu isolamento fácil e extensivo potencial de diferenciação, as CTM estão entre as primeiras células-tronco a serem introduzidas na prática clínica [108].

As CTM têm grande potencial para ser empregado em terapias celulares, visto sua facilidade de obtenção, expansão e diferenciação, além de relativa aceitação do ponto de vista ético [109-111]. Estas podem se diferenciar em uma variedade de células não hematopoiéticas. Demonstrou-se que as CTM, quando injetadas em animais, são capazes de migrar para a área da lesão e restaurar a função do tecido [109]. Além disso, as CTM podem repovoar órgãos danificados e serem usadas como vetores de transporte gênico e de fatores de crescimento para sítios privilegiados depois de transdução. Esta medicina reparativa ou regenerativa está sendo atualmente empregada no tratamento de diversas doenças hematológicas neoplásicas ou não, e vem sendo estendida para outros campos de atuação com resultados promissores, tais como coração, artérias e cérebro [108, 112, 113]. Morfologicamente, as CTM são células fusiformes, com formato 
semelhante a fibroblastos, e apresenta caracteristicamente, no início de seu crescimento in vitro, formação de unidades formadoras de colônias (CFU). Fenotipicamente, elas são negativas para marcadores de superfície hematopoiéticas, CD34, CD45, CD14, CD133, e positivas para CD29, CD73, CD90, CD105, CD166, CD54, CD55, CD13 e CD44 [109, 113, 114].

\subsection{CTM e a inibição da resposta imune}

Um estudo mostrou a capacidade das CTM em evitar a rejeição a aloenxertos em modelos animais [115]. Bartholomew e cols. em 2002 mostraram in vivo que a administração de CTM alogenêicas prolongava a sobrevida de enxerto de pele de um terceiro doador em modelo animal, suprimindo a resposta de células T [116]. Aggarwal e cols. em 2005 mostraram o potencial dessas células em criar um micro-ambiente tolerogênico, levando ao aceite do tecido transplantado, sugerindo também uma participação de células reguladoras $\mathrm{T} \mathrm{CD}^{+} \mathrm{CD}^{2} 5^{+}$[117]. Existem mecanismos que poderiam contribuir para este efeito, entre eles a carência de moléculas de classe II do MHC [118] e de moléculas co-estimulatórias, como CD80, CD86 e CD40 [119]. De forma interessante, a transfecção das CTM com as moléculas CD80 e CD86 não reverteu esta capacidade de inibir resposta imune [120]. Lyushnenkova e cols. demonstraram que na verdade, esta capacidade supressora estava relacionada à produção de citocinas solúveis como IL-10 e não dependia da presença destas moléculas co-estimulatórias [120].

Outro mecanismo descrito envolveria a participação das células dendríticas. Sabe-se que células dendríticas imaturas podem expandir populações de células Treg [121, 122], e acredita-se que este processo contribuiria para a sobrevivência do enxerto [123]. Esta capacidade das células dendríticas em induzir tolerância periférica, é um dos

potenciais mecanismos pelos quais as CTM poderiam manipular a imunidade 
adaptativa. Deste modo, as CTM poderiam prevenir respostas alogenêicas através da modulação das células dendríticas ou diretamente sobre as células T [124]. Em 2005, Maccario e colegas descreveram a capacidade de CTM humanas de induzir a diferenciação de células $\mathrm{T} \mathrm{CD}^{+}$para um fenótipo supressor ou regulador [125]. Recentemente, Pierdomenico et al. demonstraram que estas células inibiam a resposta proliferativa de linfócitos T CD4+ frente a estímulo policlonal em quase 90\% [126].

Contudo, a aquisição das CTM de medula é um método trabalhoso e dolorido para o paciente. As células-tronco derivadas do tecido adiposo (ADSC, do inglês Adipose-derived stem cells) são uma atraente alternativa de obtenção de CTM para uso em engenharia tecidual e aplicações clínicas [127]. Sua relativa abundância, e fácil acesso nos tecidos adultos fazem dessas células as candidatas ideais para terapia celular. Assim, tem-se proposto o uso dessas células no reparo de tecidos injuriados, ou depois de apropriada manipulação, tratamento de algumas desordens [100, 128, 129].

Um estudo minucioso realizado pelo grupo do Pesquisador Antoine Blancher comparou a capacidade imunomoduladora de CT derivadas da medula óssea com as ADSC. Nesse estudo eles puderam concluir que as duas células possuíam potencial imunossupressor, pois ambas foram capazes de conter a proliferação de linfócitos T, frente a estímulos alogenêicos ou policlonais. Eles mostraram também que essa supressão era mediada por substâncias solúveis, que não são a IL-10 e TGF- $\beta$, e também a necessidade de contato [130]. Isso nos leva a crer que as ADSC podem ser de grande uso haja vista sua grande abundância e facilidade de obtenção. Assim nós resolvemos estudar papel dessas células no modelo de transplante de pele. Neste trabalho, nós tínhamos como hipótese de trabalho que as ADSC induziriam uma tolerância imunológica em transplante experimental por influência no balanço de células $\mathrm{T}$ reguladoras (Treg) efetoras

(Th1/Th17). 


\section{CONCLUSÕES}

Com base nos nossos resultados, nós podemos concluir que as ADSC:

1. Tem capacidade de aumentar a sobrevida do transplante de pele alogenêico;

2. Induzem nas primeiras 72 horas após o transplante uma população de células $T$ $\mathrm{CD} 4{ }^{+} \mathrm{CD} 25^{+}$expressando o fator de transcrição Foxp3;

3. Após o transplante, nas primeiras 72 horas suprimem a produção de Il-17 no enxerto;

4. O tratamento com as ADSC induzem uma maior expressão de IFN- $\gamma$ nos linfonodos em 10 dias o que não observado no enxerto,

5. As ADSC suprimem a proliferação de linfócitos $\mathrm{T} C \mathrm{CD} 4^{+}$in vitro frente ao estímulo alogenêico; e

6. As ADSC inibem a produção de IL-17 e IFN- $\gamma$ in vitro pelas células T CD4 $4^{+}$frente ao estímulo alogenêico. 


\section{REFERÊNCIAS BIBLIOGRÁFICAS*}

[1] Gibson T, Medawar PB. The fate of skin homografts in man. J Anat. 1943 Jul;77(Pt 4):299-310 4.

[2] Medawar PB. The behaviour and fate of skin autografts and skin homografts in rabbits: A report to the War Wounds Committee of the Medical Research Council. J Anat. 1944 Oct;78(Pt 5):176-99.

[3] Medawar P. Second study of behaviour and fate of skin homografts in rabbits. J Anat. 1945;79(157).

[4] Medzhitov R, Janeway CA, Jr. Innate immunity: impact on the adaptive immune response. Curr Opin Immunol. 1997 Feb;9(1):4-9.

[5] Medzhitov R, Janeway CA, Jr. Decoding the patterns of self and nonself by the innate immune system. Science. 2002 Apr 12;296(5566):298-300.

[6] Schnare M, Barton GM, Holt AC, Takeda K, Akira S, Medzhitov R. Toll-like receptors control activation of adaptive immune responses. Nat Immunol. 2001 Oct;2(10):947-50.

[7] Solez K, Colvin RB, Racusen LC, Sis B, Halloran PF, Birk PE, et al. Banff '05 Meeting Report: differential diagnosis of chronic allograft injury and elimination of chronic allograft nephropathy ('CAN'). Am J Transplant. 2007 Mar;7(3):518-26.

[8] Magee CC. Transplantation across previously incompatible immunological barriers. Transpl Int. 2006 Feb;19(2):87-97.

[9] Ibrahim S, Dawson DV, Sanfilippo F. Predominant infiltration of rejecting human renal allografts with T cells expressing CD8 and CD45RO. Transplantation. 1995 Mar 15;59(5):724-8.

[10] Rocha PN, Plumb TJ, Crowley SD, Coffman TM. Effector mechanisms in transplant rejection. Immunol Rev. 2003 Dec;196:51-64.

[11] Herrera OB, Golshayan D, Tibbott R, Salcido Ochoa F, James MJ, Marelli-Berg FM, et al. A novel pathway of alloantigen presentation by dendritic cells. J Immunol. 2004 Oct 15;173(8):4828-37.

\footnotetext{
* De acordo com: International Committee of Medical Journal Editors. Uniform Requirements for Manuscripts Submitted to Biomedical Journal: Sample References. Available from: http://www.icmje.org [2007 May 22].
} 
[12] Game DS, Rogers NJ, Lechler RI. Acquisition of HLA-DR and costimulatory molecules by $\mathrm{T}$ cells from allogeneic antigen presenting cells. Am J Transplant. 2005 Jul;5(7):1614-25.

[13] Morelli AE, Larregina AT, Shufesky WJ, Sullivan ML, Stolz DB, Papworth GD, et al. Endocytosis, intracellular sorting, and processing of exosomes by dendritic cells. Blood. 2004 Nov 15;104(10):3257-66.

[14] Shen H, Tesar BM, Walker WE, Goldstein DR. Dual signaling of MyD88 and TRIF is critical for maximal TLR4-induced dendritic cell maturation. J Immunol. 2008 Aug 1;181(3):1849-58.

[15] Mosmann TR, Cherwinski H, Bond MW, Giedlin MA, Coffman RL. Two types of murine helper $\mathrm{T}$ cell clone. I. Definition according to profiles of lymphokine activities and secreted proteins. J Immunol. 1986 Apr 1;136(7):2348-57.

[16] Killar L, MacDonald G, West J, Woods A, Bottomly K. Cloned, la-restricted T cells that do not produce interleukin 4(IL 4)/B cell stimulatory factor 1(BSF-1) fail to help antigen-specific B cells. J Immunol. 1987 Mar 15;138(6):1674-9.

[17] Le Gros G, Ben-Sasson SZ, Seder R, Finkelman FD, Paul WE. Generation of interleukin 4 (IL-4)-producing cells in vivo and in vitro: IL-2 and IL-4 are required for in vitro generation of IL-4-producing cells. J Exp Med. 1990 Sep 1;172(3):921-9.

[18] Zheng W, Flavell RA. The transcription factor GATA-3 is necessary and sufficient for Th2 cytokine gene expression in CD4 T cells. Cell. 1997 May 16;89(4):587-96.

[19] Zhang DH, Cohn L, Ray P, Bottomly K, Ray A. Transcription factor GATA-3 is differentially expressed in murine Th1 and Th2 cells and controls Th2-specific expression of the interleukin-5 gene. J Biol Chem. 1997 Aug 22;272(34):21597-603.

[20] Szabo SJ, Kim ST, Costa GL, Zhang X, Fathman CG, Glimcher LH. A novel transcription factor, T-bet, directs Th1 lineage commitment. Cell. 2000 Mar 17;100(6):655-69.

[21] Lighvani AA, Frucht DM, Jankovic D, Yamane H, Aliberti J, Hissong BD, et al. T-bet is rapidly induced by interferon-gamma in lymphoid and myeloid cells. Proc Natl Acad Sci U S A. 2001 Dec 18;98(26):15137-42.

[22] Hopt UT, Sullivan W, Hoffman R, Simmons RL. Migration and cell recruiting activity of specifically sensitized lymphocytes in sponge matrix allografts. Transplantation. 1980 Dec;30(6):411-6.

[23] Takiishi T. Caracterização da resposta inflamatória no enxerto singênico e alogênico em modelo experimental de transplante de pele. 2008 
[24] Krieger NR, Yin DP, Fathman CG. CD4+ but not CD8+ cells are essential for allorejection. J Exp Med. 1996 Nov 1;184(5):2013-8.

[25] Zhao Y, Swenson K, Wekerle T, Rodriguez-Barbosa JI, Arn JS, Sykes M. The critical role of mouse CD4+ cells in the rejection of highly disparate xenogeneic pig thymus grafts. Xenotransplantation. 2000 May;7(2):129-37.

[26] Bishop DK, Chan Wood S, Eichwald EJ, Orosz CG. Immunobiology of allograft rejection in the absence of IFN-gamma: CD8+ effector cells develop independently of CD4+ cells and CD40-CD40 ligand interactions. J Immunol. 2001 Mar 1;166(5):324855.

[27] Christianson SW, Shultz LD, Leiter EH. Adoptive transfer of diabetes into immunodeficient NOD-scid/scid mice. Relative contributions of CD4+ and CD8+ T-cells from diabetic versus prediabetic NOD.NON-Thy-1a donors. Diabetes. 1993 Jan;42(1):44-55.

[28] Rosenberg AS, Mizuochi T, Sharrow SO, Singer A. Phenotype, specificity, and function of $T$ cell subsets and $T$ cell interactions involved in skin allograft rejection. $J$ Exp Med. 1987 May 1;165(5):1296-315.

[29] Basha G, Lizee G, Reinicke AT, Seipp RP, Omilusik KD, Jefferies WA. MHC class I endosomal and lysosomal trafficking coincides with exogenous antigen loading in dendritic cells. PLoS One. 2008;3(9):e3247.

[30] Youssef AR, Otley C, Mathieson PW, Smith RM. Role of CD4+ and CD8+ T cells in murine skin and heart allograft rejection across different antigenic desparities. Transpl Immunol. 2004 Dec;13(4):297-304.

[31] Kimura A, Naka T, Kishimoto T. IL-6-dependent and -independent pathways in the development of interleukin 17-producing T helper cells. Proc Natl Acad Sci U S A. 2007 Jul 17;104(29):12099-104.

[32] Steinman L. A brief history of $T(H) 17$, the first major revision in the $T(H) 1 / T(H) 2$ hypothesis of T cell-mediated tissue damage. Nat Med. 2007 Feb;13(2):139-45.

[33] Ivanov, II, Zhou L, Littman DR. Transcriptional regulation of Th17 cell differentiation. Semin Immunol. 2007 Dec;19(6):409-17.

[34] McGeachy MJ, Cua DJ. Th17 cell differentiation: the long and winding road. Immunity. 2008 Apr;28(4):445-53. 
[35] Mathur AN, Chang HC, Zisoulis DG, Stritesky GL, Yu Q, O'Malley JT, et al. Stat3 and Stat4 direct development of IL-17-secreting Th cells. J Immunol. 2007 Apr 15;178(8):4901-7.

[36] Fiorentino DF, Bond MW, Mosmann TR. Two types of mouse T helper cell. IV. Th2 clones secrete a factor that inhibits cytokine production by Th1 clones. J Exp Med. 1989 Dec 1;170(6):2081-95.

[37] Roncarolo MG, Gregori S, Battaglia M, Bacchetta R, Fleischhauer K, Levings MK. Interleukin-10-secreting type 1 regulatory T cells in rodents and humans. Immunol Rev. 2006 Aug;212:28-50.

[38] Jankovic D, Trinchieri G. IL-10 or not IL-10: that is the question. Nat Immunol. 2007 Dec;8(12):1281-3.

[39] Stumhofer JS, Silver JS, Laurence A, Porrett PM, Harris TH, Turka LA, et al. Interleukins 27 and 6 induce STAT3-mediated T cell production of interleukin 10. Nat Immunol. 2007 Dec;8(12):1363-71.

[40] Awasthi A, Carrier Y, Peron JP, Bettelli E, Kamanaka M, Flavell RA, et al. A dominant function for interleukin 27 in generating interleukin 10-producing antiinflammatory T cells. Nat Immunol. 2007 Dec;8(12):1380-9.

[41] Cobbold SP. The hidden truth about gene expression in Tregs: is it what you don't see that counts? Eur J Immunol. 2006 Jun;36(6):1360-3.

[42] Goldrath AW, Hedrick SM. Central tolerance matters. Immunity. 2005 Aug;23(2):113-4.

[43] Anderson MS, Venanzi ES, Klein L, Chen Z, Berzins SP, Turley SJ, et al. Projection of an immunological self shadow within the thymus by the aire protein. Science. 2002 Nov 15;298(5597):1395-401.

[44] Anderson MS, Venanzi ES, Chen Z, Berzins SP, Benoist C, Mathis D. The cellular mechanism of Aire control of T cell tolerance. Immunity. 2005 Aug;23(2):227-39.

[45] Cohen IR. The cognitive paradigm and the immunological homunculus. Immunol Today. 1992 Dec;13(12):490-4.

[46] Cohen IR. Biomarkers, self-antigens and the immunological homunculus. J Autoimmun. 2007 Dec;29(4):246-9.

[47] Luna E, Postol E, Caldas C, Mundel LR, Porto G, Iwai LK, et al. Diversity of physiological cell reactivity to heat shock protein 60 in different mouse strains. Cell Stress Chaperones. 2007 Summer;12(2):112-22. 
[48] Barron L, Knoechel B, Lohr J, Abbas AK. Cutting edge: contributions of apoptosis and anergy to systemic T cell tolerance. J Immunol. 2008 Mar 1;180(5):2762-6.

[49] Bluestone JA. Is CTLA-4 a master switch for peripheral T cell tolerance? J Immunol. 1997 Mar 1;158(5):1989-93.

[50] Greenwald RJ, Boussiotis VA, Lorsbach RB, Abbas AK, Sharpe AH. CTLA-4 regulates induction of anergy in vivo. Immunity. 2001 Feb;14(2):145-55.

[51] Anderson PO, Manzo BA, Sundstedt A, Minaee S, Symonds A, Khalid S, et al. Persistent antigenic stimulation alters the transcription program in $\mathrm{T}$ cells, resulting in antigen-specific tolerance. Eur J Immunol. 2006 Jun;36(6):1374-85.

[52] Miller JF, Heath WR. Self-ignorance in the peripheral T-cell pool. Immunol Rev. 1993 Jun;133:131-50.

[53] Carrier Y, Yuan J, Kuchroo VK, Weiner HL. Th3 cells in peripheral tolerance. I. Induction of Foxp3-positive regulatory T cells by Th3 cells derived from TGF-beta T celltransgenic mice. J Immunol. 2007 Jan 1;178(1):179-85.

[54] Carrier Y, Yuan J, Kuchroo VK, Weiner HL. Th3 cells in peripheral tolerance. II. TGF-beta-transgenic Th3 cells rescue IL-2-deficient mice from autoimmunity. J Immunol. 2007 Jan 1;178(1):172-8.

[55] Chen TC, Cobbold SP, Fairchild PJ, Waldmann H. Generation of anergic and regulatory $T$ cells following prolonged exposure to a harmless antigen. J Immunol. 2004 May 15;172(10):5900-7.

[56] Chen Y, Inobe J, Marks R, Gonnella P, Kuchroo VK, Weiner HL. Peripheral deletion of antigen-reactive T cells in oral tolerance. Nature. 1995 Jul 13;376(6536):177-80.

[57] Romball CG, Weigle WO. Cytokines in the induction and circumvention of peripheral tolerance. J Interferon Cytokine Res. 1999 Jun;19(6):671-8.

[58] Sakaguchi S, Sakaguchi N, Asano M, Itoh M, Toda M. Immunologic self-tolerance maintained by activated $T$ cells expressing IL-2 receptor alpha-chains (CD25). Breakdown of a single mechanism of self-tolerance causes various autoimmune diseases. J Immunol. 1995 Aug 1;155(3):1151-64.

[59] Seino KI, Fukao K, Muramoto K, Yanagisawa K, Takada Y, Kakuta S, et al. Requirement for natural killer T (NKT) cells in the induction of allograft tolerance. Proc Natl Acad Sci U S A. 2001 Feb 27;98(5):2577-81.

[60] Beilke JN, Kuhl NR, Van Kaer L, Gill RG. NK cells promote islet allograft tolerance via a perforin-dependent mechanism. Nat Med. 2005 Oct;11(10):1059-65. 
[61] Filaci G, Fravega M, Negrini S, Procopio F, Fenoglio D, Rizzi M, et al. Nonantigen specific CD8+ T suppressor lymphocytes originate from CD8+CD28- $T$ cells and inhibit both T-cell proliferation and CTL function. Hum Immunol. 2004 Feb;65(2):142-56.

[62] Manavalan JS, Kim-Schulze S, Scotto L, Naiyer AJ, Vlad G, Colombo PC, et al. Alloantigen specific CD8+CD28- FOXP3+ T suppressor cells induce ILT3+ ILT4+ tolerogenic endothelial cells, inhibiting alloreactivity. Int Immunol. 2004 Aug;16(8):105568.

[63] Cosmi L, Liotta F, Lazzeri E, Francalanci M, Angeli R, Mazzinghi B, et al. Human CD8+CD25+ thymocytes share phenotypic and functional features with CD4+CD25+ regulatory thymocytes. Blood. 2003 Dec 1;102(12):4107-14.

[64] Chattopadhyay S, Mehrotra S, Chhabra A, Hegde U, Mukherji B, Chakraborty NG. Effect of CD4+CD25+ and CD4+CD25- T regulatory cells on the generation of cytolytic $\mathrm{T}$ cell response to a self but human tumor-associated epitope in vitro. J Immunol. 2006 Jan 15;176(2):984-90.

[65] Kapp JA, Kapp LM, McKenna KC. Gammadelta T cells play an essential role in several forms of tolerance. Immunol Res. 2004;29(1-3):93-102.

[66] Kapp JA, Kapp LM, McKenna KC, Lake JP. gammadelta T-cell clones from intestinal intraepithelial lymphocytes inhibit development of CTL responses ex vivo. Immunology. 2004 Feb;111(2):155-64.

[67] Groux H, O'Garra A, Bigler M, Rouleau M, Antonenko S, de Vries JE, et al. A CD4+ T-cell subset inhibits antigen-specific T-cell responses and prevents colitis. Nature. 1997 Oct 16;389(6652):737-42.

[68] Chen Y, Kuchroo VK, Inobe J, Hafler DA, Weiner HL. Regulatory T cell clones induced by oral tolerance: suppression of autoimmune encephalomyelitis. Science. 1994 Aug 26;265(5176):1237-40.

[69] Piccirillo CA, Shevach EM. Cutting edge: control of CD8+ T cell activation by CD4+CD25+ immunoregulatory cells. J Immunol. 2001 Aug 1;167(3):1137-40.

[70] Dieckmann D, Plottner H, Berchtold S, Berger T, Schuler G. Ex vivo isolation and characterization of $\mathrm{CD} 4(+) \mathrm{CD} 25(+) \mathrm{T}$ cells with regulatory properties from human blood. J Exp Med. 2001 Jun 4;193(11):1303-10.

[71] Fontenot JD, Gavin MA, Rudensky AY. Foxp3 programs the development and function of CD4+CD25+ regulatory T cells. Nat Immunol. 2003 Apr;4(4):330-6.

[72] Li S, Weidenfeld J, Morrisey EE. Transcriptional and DNA binding activity of the Foxp1/2/4 family is modulated by heterotypic and homotypic protein interactions. Mol Cell Biol. 2004 Jan;24(2):809-22. 
[73] Walker MR, Kasprowicz DJ, Gersuk VH, Benard A, Van Landeghen M, Buckner JH, et al. Induction of FoxP3 and acquisition of T regulatory activity by stimulated human CD4+CD25- T cells. J Clin Invest. 2003 Nov;112(9):1437-43.

[74] Ziegler SF. FOXP3: of mice and men. Annu Rev Immunol. 2006;24:209-26.

[75] Mantel PY, Ouaked N, Ruckert B, Karagiannidis C, Welz R, Blaser K, et al. Molecular mechanisms underlying FOXP3 induction in human T cells. J Immunol. 2006 Mar 15;176(6):3593-602.

[76] Setoguchi R, Hori S, Takahashi T, Sakaguchi S. Homeostatic maintenance of natural Foxp3(+) CD25(+) CD4(+) regulatory T cells by interleukin (IL)-2 and induction of autoimmune disease by IL-2 neutralization. J Exp Med. 2005 Mar 7;201(5):723-35.

[77] Fontenot JD, Rasmussen JP, Gavin MA, Rudensky AY. A function for interleukin 2 in Foxp3-expressing regulatory T cells. Nat Immunol. 2005 Nov;6(11):1142-51.

[78] Bayer AL, Yu A, Malek TR. Function of the IL-2R for thymic and peripheral CD4+CD25+ Foxp3+ T regulatory cells. J Immunol. 2007 Apr 1;178(7):4062-71.

[79] Read S, Malmstrom V, Powrie F. Cytotoxic T lymphocyte-associated antigen 4 plays an essential role in the function of CD25(+)CD4(+) regulatory cells that control intestinal inflammation. J Exp Med. 2000 Jul 17;192(2):295-302.

[80] Bruder D, Probst-Kepper M, Westendorf AM, Geffers R, Beissert S, Loser K, et al. Neuropilin-1: a surface marker of regulatory T cells. Eur J Immunol. 2004 Mar;34(3):623-30.

[81] Huang CT, Workman CJ, Flies D, Pan X, Marson AL, Zhou G, et al. Role of LAG-3 in regulatory T cells. Immunity. 2004 Oct;21(4):503-13.

[82] McHugh RS, Whitters MJ, Piccirillo CA, Young DA, Shevach EM, Collins M, et al. CD4(+)CD25(+) immunoregulatory $T$ cells: gene expression analysis reveals a functional role for the glucocorticoid-induced TNF receptor. Immunity. 2002 Feb;16(2):311-23.

[83] Iellem A, Mariani M, Lang $R$, Recalde $H$, Panina-Bordignon $P$, Sinigaglia $F$, et al. Unique chemotactic response profile and specific expression of chemokine receptors CCR4 and CCR8 by CD4(+)CD25(+) regulatory T cells. J Exp Med. 2001 Sep 17;194(6):847-53.

[84] Taylor PA, Panoskaltsis-Mortari A, Swedin JM, Lucas PJ, Gress RE, Levine BL, et al. L-Selectin(hi) but not the L-selectin(lo) CD4+25+ T-regulatory cells are potent inhibitors of GVHD and BM graft rejection. Blood. 2004 Dec 1;104(12):3804-12. 
[85] Kingsley $\mathrm{Cl}$, Karim M, Bushell AR, Wood KJ. CD25+CD4+ regulatory $\mathrm{T}$ cells prevent graft rejection: CTLA-4- and IL-10-dependent immunoregulation of alloresponses. J Immunol. 2002 Feb 1;168(3):1080-6.

[86] Read S, Greenwald R, Izcue A, Robinson N, Mandelbrot D, Francisco L, et al. Blockade of CTLA-4 on CD4+CD25+ regulatory T cells abrogates their function in vivo. J Immunol. 2006 Oct 1;177(7):4376-83.

[87] You S, Leforban B, Garcia C, Bach JF, Bluestone JA, Chatenoud L. Adaptive TGFbeta-dependent regulatory $T$ cells control autoimmune diabetes and are a privileged target of anti-CD3 antibody treatment. Proc Natl Acad Sci U S A. 2007 Apr 10;104(15):6335-40.

[88] Pandiyan P, Zheng L, Ishihara S, Reed J, Lenardo MJ. CD4+CD25+Foxp3+ regulatory $T$ cells induce cytokine deprivation-mediated apoptosis of effector CD4+ T cells. Nat Immunol. 2007 Dec;8(12):1353-62.

[89] de la Rosa M, Rutz S, Dorninger $\mathrm{H}$, Scheffold A. Interleukin-2 is essential for CD4+CD25+ regulatory T cell function. Eur J Immunol. 2004 Sep;34(9):2480-8.

[90] Gondek DC, Lu LF, Quezada SA, Sakaguchi S, Noelle RJ. Cutting edge: contactmediated suppression by $\mathrm{CD} 4+\mathrm{CD} 25+$ regulatory cells involves a granzyme Bdependent, perforin-independent mechanism. J Immunol. 2005 Feb 15;174(4):1783-6.

[91] Bopp T, Becker C, Klein M, Klein-Hessling S, Palmetshofer A, Serfling E, et al. Cyclic adenosine monophosphate is a key component of regulatory $\mathrm{T}$ cell-mediated suppression. J Exp Med. 2007 Jun 11;204(6):1303-10.

[92] Bodor J, Fehervari Z, Diamond B, Sakaguchi S. ICER/CREM-mediated transcriptional attenuation of IL-2 and its role in suppression by regulatory T cells. Eur J Immunol. 2007 Apr;37(4):884-95.

[93] Bodor J, Fehervari Z, Diamond B, Sakaguchi S. Regulatory T cell-mediated suppression: potential role of ICER. J Leukoc Biol. 2007 Jan;81(1):161-7.

[94] Bodor J, Feigenbaum L, Bodorova J, Bare C, Reitz MS, Jr., Gress RE. Suppression of T-cell responsiveness by inducible cAMP early repressor (ICER). J Leukoc Biol. 2001 Jun;69(6):1053-9.

[95] Deaglio S, Dwyer KM, Gao W, Friedman D, Usheva A, Erat A, et al. Adenosine generation catalyzed by $\mathrm{CD} 39$ and $\mathrm{CD} 73$ expressed on regulatory $\mathrm{T}$ cells mediates immune suppression. J Exp Med. 2007 Jun 11;204(6):1257-65.

[96] Sharma MD, Baban B, Chandler P, Hou DY, Singh N, Yagita H, et al. Plasmacytoid dendritic cells from mouse tumor-draining lymph nodes directly activate mature Tregs via indoleamine 2,3-dioxygenase. J Clin Invest. 2007 Sep;117(9):2570-82. 
[97] Wood KJ, Sakaguchi S. Regulatory T cells in transplantation tolerance. Nat Rev Immunol. 2003 Mar;3(3):199-210.

[98] Ramalho-Santos $\mathrm{M}$, Willenbring $\mathrm{H}$. On the origin of the term "stem cell". Cell Stem Cell. 2007 Jun 7;1(1):35-8.

[99] Health N-Nlo: In.

[100] Pittenger MF, Mackay AM, Beck SC, Jaiswal RK, Douglas R, Mosca JD, et al. Multilineage potential of adult human mesenchymal stem cells. Science. $1999 \mathrm{Apr}$ 2;284(5411):143-7.

[101] Moore KA, Lemischka IR. Stem cells and their niches. Science. 2006 Mar 31;311(5769):1880-5.

[102] Sujata L, Chaudhuri S. Stem cell niche, the microenvironment and immunological crosstalk. Cell Mol Immunol. 2008 Apr;5(2):107-12.

[103] Caplan Al. Why are MSCs therapeutic? New data: new insight. J Pathol. 2009 Jan;217(2):318-24.

[104] Le Blanc K, Pittenger M. Mesenchymal stem cells: progress toward promise. Cytotherapy. 2005;7(1):36-45.

[105] Togel F, Weiss K, Yang Y, Hu Z, Zhang P, Westenfelder C. Vasculotropic, paracrine actions of infused mesenchymal stem cells are important to the recovery from acute kidney injury. Am J Physiol Renal Physiol. 2007 May;292(5):F1626-35.

[106] Humphreys BD, Bonventre JV. Mesenchymal stem cells in acute kidney injury. Annu Rev Med. 2008;59:311-25.

[107] Uccelli A, Moretta L, Pistoia V. Mesenchymal stem cells in health and disease. Nat Rev Immunol. 2008 Sep;8(9):726-36.

[108] Kassem M. Mesenchymal stem cells: biological characteristics and potential clinical applications. Cloning Stem Cells. 2004;6(4):369-74.

[109] Ding S, Schultz PG. A role for chemistry in stem cell biology. Nat Biotechnol. 2004 Jul;22(7):833-40.

[110] Oliver JA, Maarouf O, Cheema FH, Martens TP, Al-Awqati Q. The renal papilla is a niche for adult kidney stem cells. J Clin Invest. 2004 Sep;114(6):795-804.

[111] Baksh D, Song L, Tuan RS. Adult mesenchymal stem cells: characterization, differentiation, and application in cell and gene therapy. J Cell Mol Med. 2004 JulSep;8(3):301-16. 
[112] Spangrude GJ. When is a stem cell really a stem cell? Bone Marrow Transplant. 2003 Aug;32 Suppl 1:S7-11.

[113] Kassem M, Kristiansen M, Abdallah BM. Mesenchymal stem cells: cell biology and potential use in therapy. Basic Clin Pharmacol Toxicol. 2004 Nov;95(5):209-14.

[114] Sakaguchi S. Naturally arising CD4+ regulatory t cells for immunologic selftolerance and negative control of immune responses. Annu Rev Immunol. 2004;22:53162.

[115] Ryan JM, Barry FP, Murphy JM, Mahon BP. Mesenchymal stem cells avoid allogeneic rejection. J Inflamm (Lond). 2005 Jul 26;2:8.

[116] Bartholomew A, Sturgeon C, Siatskas M, Ferrer K, Mclntosh K, Patil S, et al. Mesenchymal stem cells suppress lymphocyte proliferation in vitro and prolong skin graft survival in vivo. Exp Hematol. 2002 Jan;30(1):42-8.

[117] Aggarwal S, Pittenger MF. Human mesenchymal stem cells modulate allogeneic immune cell responses. Blood. 2005 Feb 15;105(4):1815-22.

[118] Krampera M, Glennie S, Dyson J, Scott D, Laylor R, Simpson E, et al. Bone marrow mesenchymal stem cells inhibit the response of naive and memory antigenspecific T cells to their cognate peptide. Blood. 2003 May 1;101(9):3722-9.

[119] Tse WT, Pendleton JD, Beyer WM, Egalka MC, Guinan EC. Suppression of allogeneic $\mathrm{T}$-cell proliferation by human marrow stromal cells: implications in transplantation. Transplantation. 2003 Feb 15;75(3):389-97.

[120] Klyushnenkova E, Mosca JD, Zernetkina V, Majumdar MK, Beggs KJ, Simonetti $\mathrm{DW}$, et al. $\mathrm{T}$ cell responses to allogeneic human mesenchymal stem cells: immunogenicity, tolerance, and suppression. J Biomed Sci. 2005;12(1):47-57.

[121] Steinman RM, Nussenzweig MC. Avoiding horror autotoxicus: the importance of dendritic cells in peripheral T cell tolerance. Proc Natl Acad Sci U S A. 2002 Jan 8;99(1):351-8.

[122] Mills $\mathrm{KH}$. Regulatory $\mathrm{T}$ cells: friend or foe in immunity to infection? Nat Rev Immunol. 2004 Nov;4(11):841-55.

[123] Niederkorn JY, Peeler JS, Ross J, Callanan D. The immunogenic privilege of corneal allografts. Reg Immunol. 1989 Mar-Apr;2(2):117-24.

[124] Jiang XX, Zhang Y, Liu B, Zhang SX, Wu Y, Yu XD, et al. Human mesenchymal stem cells inhibit differentiation and function of monocyte-derived dendritic cells. Blood. 2005 May 15;105(10):4120-6. 
[125] Maccario R, Podesta M, Moretta A, Cometa A, Comoli P, Montagna D, et al. Interaction of human mesenchymal stem cells with cells involved in alloantigen-specific immune response favors the differentiation of CD4+ T-cell subsets expressing a regulatory/suppressive phenotype. Haematologica. 2005 Apr;90(4):516-25.

[126] Pierdomenico L, Bonsi L, Calvitti M, Rondelli D, Arpinati M, Chirumbolo G, et al. Multipotent mesenchymal stem cells with immunosuppressive activity can be easily isolated from dental pulp. Transplantation. 2005 Sep 27;80(6):836-42.

[127] Zuk PA, Zhu M, Ashjian P, De Ugarte DA, Huang JI, Mizuno H, et al. Human adipose tissue is a source of multipotent stem cells. Mol Biol Cell. 2002 Dec;13(12):4279-95.

[128] Sekiya I, Larson BL, Smith JR, Pochampally R, Cui JG, Prockop DJ. Expansion of human adult stem cells from bone marrow stroma: conditions that maximize the yields of early progenitors and evaluate their quality. Stem Cells. 2002;20(6):530-41.

[129] Kawada H, Fujita J, Kinjo K, Matsuzaki Y, Tsuma M, Miyatake H, et al. Nonhematopoietic mesenchymal stem cells can be mobilized and differentiate into cardiomyocytes after myocardial infarction. Blood. 2004 Dec 1;104(12):3581-7.

[130] Puissant B, Barreau C, Bourin P, Clavel C, Corre J, Bousquet C, et al. Immunomodulatory effect of human adipose tissue-derived adult stem cells: comparison with bone marrow mesenchymal stem cells. Br J Haematol. 2005 Apr;129(1):118-29.

[131] Bruder SP, Jaiswal N, Haynesworth SE. Growth kinetics, self-renewal, and the osteogenic potential of purified human mesenchymal stem cells during extensive subcultivation and following cryopreservation. J Cell Biochem. 1997 Feb;64(2):278-94.

[132] Janderova L, McNeil M, Murrell AN, Mynatt RL, Smith SR. Human mesenchymal stem cells as an in vitro model for human adipogenesis. Obes Res. 2003 Jan;11(1):6574.

[133] Jaiswal N, Haynesworth SE, Caplan AI, Bruder SP. Osteogenic differentiation of purified, culture-expanded human mesenchymal stem cells in vitro. J Cell Biochem. 1997 Feb;64(2):295-312.

[134] Chomczynski $P$, Sacchi N. Single-step method of RNA isolation by acid guanidinium thiocyanate-phenol-chloroform extraction. Anal Biochem. 1987 Apr;162(1):156-9.

[135] Schmittgen TD, Livak KJ. Analyzing real-time PCR data by the comparative $C(T)$ method. Nat Protoc. 2008;3(6):1101-8. 
[136] Friedenstein AJ, Chailakhjan RK, Lalykina KS. The development of fibroblast colonies in monolayer cultures of guinea-pig bone marrow and spleen cells. Cell Tissue Kinet. 1970 Oct;3(4):393-403.

[137] da Silva Meirelles L, Chagastelles PC, Nardi NB. Mesenchymal stem cells reside in virtually all post-natal organs and tissues. J Cell Sci. 2006 Jun 1;119(Pt 11):2204-13.

[138] Dominici M, Le Blanc K, Mueller I, Slaper-Cortenbach I, Marini F, Krause D, et al. Minimal criteria for defining multipotent mesenchymal stromal cells. The International Society for Cellular Therapy position statement. Cytotherapy. 2006;8(4):315-7.

[139] Ringden O, Uzunel M, Rasmusson I, Remberger M, Sundberg B, Lonnies H, et al. Mesenchymal stem cells for treatment of therapy-resistant graft-versus-host disease. Transplantation. 2006 May 27;81(10):1390-7.

[140] Veldhoen M, Hocking RJ, Atkins CJ, Locksley RM, Stockinger B. TGFbeta in the context of an inflammatory cytokine milieu supports de novo differentiation of IL-17producing T cells. Immunity. 2006 Feb;24(2):179-89.

[141] Atalar K, Afzali B, Lord G, Lombardi G. Relative roles of Th1 and Th17 effector cells in allograft rejection. Curr Opin Organ Transplant. 2009 Feb;14(1):23-9.

[142] Sesso R, Yoshihiro MM. Time of diagnosis of chronic renal failure and assessment of quality of life in haemodialysis patients. Nephrol Dial Transplant. 1997 Oct;12(10):2111-6.

[143] Neto JF, Ferraz MB, Cendoroglo M, Draibe S, Yu L, Sesso R. Quality of life at the initiation of maintenance dialysis treatment--a comparison between the SF-36 and the KDQ questionnaires. Qual Life Res. 2000 Feb;9(1):101-7.

[144] Sesso R, Rodrigues-Neto JF, Ferraz MB. Impact of socioeconomic status on the quality of life of ESRD patients. Am J Kidney Dis. 2003 Jan;41(1):186-95.

[145] Djamali A, Premasathian N, Pirsch JD. Outcomes in kidney transplantation. Semin Nephrol. 2003 May;23(3):306-16.

[146] Wolfe RA, Ashby VB, Milford EL, Ojo AO, Ettenger RE, Agodoa LY, et al. Comparison of mortality in all patients on dialysis, patients on dialysis awaiting transplantation, and recipients of a first cadaveric transplant. N Engl J Med. 1999 Dec 2;341(23):1725-30.

[147] Health BNIo. United States Renal Data System, URSDS 2002 annual data report. 2002.

[148] Relatório Anual da ABTO -. 2008. 
[149] Le Blanc K, Rasmusson I, Sundberg B, Gotherstrom C, Hassan M, Uzunel M, et al. Treatment of severe acute graft-versus-host disease with third party haploidentical mesenchymal stem cells. Lancet. 2004 May 1;363(9419):1439-41.

[150] Krampera M, Pasini A, Pizzolo G, Cosmi L, Romagnani S, Annunziato F. Regenerative and immunomodulatory potential of mesenchymal stem cells. Curr Opin Pharmacol. 2006 Aug;6(4):435-41.

[151] Salmon JK, Armstrong CA, Ansel JC. The skin as an immune organ. West J Med. 1994 Feb;160(2):146-52.

[152] Murray JE. Organ transplantation (skin, kidney, heart) and the plastic surgeon. Plast Reconstr Surg. 1971 May;47(5):425-31.

[153] Streilein JW. Skin-associated lymphoid tissue. Immunol Ser. 1989;46:73-96.

[154] Lopez MM, Valenzuela JE, Alvarez FC, Lopez-Alvarez MR, Cecilia GS, Paricio PP. Long-term problems related to immunosuppression. Transpl Immunol. 2006 Dec;17(1):31-5.

[155] Billingham RE, Brent L, Medawar PB. Actively acquired tolerance of foreign cells. Nature. 1953 Oct 3;172(4379):603-6.

[156] Chen T, Xu H, Wang HQ, Zhao Y, Zhu CF, Zhang YH, et al. Prolongation of rat intestinal allograft survival by administration of triptolide-modified donor bone marrowderived dendritic cells. Transplant Proc. 2008 Dec;40(10):3711-3.

[157] Zhou HP, Yi DH, Yu SQ, Sun GC, Cui Q, Zhu HL, et al. Administration of donorderived mesenchymal stem cells can prolong the survival of rat cardiac allograft. Transplant Proc. 2006 Nov;38(9):3046-51.

[158] Fazekasova H, Golshayan D, Read J, Tsallios A, Tsang JY, Dorling A, et al. Regulation of rat and human T-cell immune response by pharmacologically modified dendritic cells. Transplantation. 2009 Jun 15;87(11):1617-28.

[159] Huang W, Ye Q, Huang Z, Yang D, Peng M. [Experimental study on induction of skin allograft tolerance in mice by heat shock protein 60]. Zhongguo Xiu Fu Chong Jian Wai Ke Za Zhi. 2008 Aug;22(8):993-7.

[160] Constantin G, Marconi S, Rossi B, Angiari S, Calderan L, Anghileri E, et al. Adipose-Derived Mesenchymal Stem Cells Ameliorate Chronic Experimental Autoimmune Encephalomyelitis. Stem Cells. 2009 Aug 12.

[161] Ding Y, Xu D, Feng G, Bushell A, Muschel RJ, Wood KJ. Mesenchymal stem cells prevent the rejection of fully allogenic islet grafts by the immunosuppressive activity of matrix metalloproteinase-2 and -9. Diabetes. 2009 Aug;58(8):1797-806. 
[162] Yang SH, Park MJ, Yoon IH, Kim SY, Hong SH, Shin JY, et al. Soluble mediators from mesenchymal stem cells suppress $T$ cell proliferation by inducing IL-10. Exp Mol Med. 2009 May 31;41(5):315-24.

[163] Asari S, Itakura S, Ferreri K, Liu CP, Kuroda Y, Kandeel F, et al. Mesenchymal stem cells suppress B-cell terminal differentiation. Exp Hematol. 2009 May;37(5):60415.

[164] Zhu Y, Liu T, Song K, Fan X, Ma X, Cui Z. Adipose-derived stem cell: a better stem cell than BMSC. Cell Biochem Funct. 2008 Aug;26(6):664-75.

[165] Mizuno H, Zuk PA, Zhu M, Lorenz HP, Benhaim P, Hedrick MH. Myogenic differentiation by human processed lipoaspirate cells. Plast Reconstr Surg. 2002 Jan;109(1):199-209; discussion 10-1.

[166] Barry FP, Murphy JM. Mesenchymal stem cells: clinical applications and biological characterization. Int J Biochem Cell Biol. 2004 Apr;36(4):568-84.

[167] Sung JH, Yang HM, Park JB, Choi GS, Joh JW, Kwon CH, et al. Isolation and characterization of mouse mesenchymal stem cells. Transplant Proc. 2008 Oct;40(8):2649-54.

[168] Renner P, Eggenhofer E, Rosenauer A, Popp FC, Steinmann JF, Slowik P, et al. Mesenchymal stem cells require a sufficient, ongoing immune response to exert their immunosuppressive function. Transplant Proc. 2009 Jul-Aug;41(6):2607-11.

[169] Grinnemo KH, Mansson A, Dellgren G, Klingberg D, Wardell E, Drvota V, et al. Xenoreactivity and engraftment of human mesenchymal stem cells transplanted into infarcted rat myocardium. J Thorac Cardiovasc Surg. 2004 May;127(5):1293-300.

[170] Hirayama S, Shiraishi T, Shirakusa T, Higuchi T, Miller EJ. Prevention of neutrophil migration ameliorates rat lung allograft rejection. Mol Med. 2006 SepOct;12(9-10):208-13.

[171] Surquin M, Buonocore S, Le Moine A, Flamand V, Goldman M, Abramowicz D. [The role of neutrophils during allograft rejection]. Nephrol Ther. 2005 Jul;1(3):161-6.

[172] Morita K, Miura M, Paolone DR, Engeman TM, Kapoor A, Remick DG, et al. Early chemokine cascades in murine cardiac grafts regulate $T$ cell recruitment and progression of acute allograft rejection. J Immunol. 2001 Sep 1;167(5):2979-84.

[173] Larocca R, Marguti I, Cabrera W, Ribeiro OG, Rizzo LV, de Moraes LV. Maximal inflammatory response benefits syngeneic skin graft acceptance. Inflamm Res. 2008 Mar 18. 
[174] Ohki Y, Heissig B, Sato Y, Akiyama H, Zhu Z, Hicklin DJ, et al. Granulocyte colony-stimulating factor promotes neovascularization by releasing vascular endothelial growth factor from neutrophils. Faseb J. 2005 Dec;19(14):2005-7.

[175] Toumi H, F'Guyer S, Best TM. The role of neutrophils in injury and repair following muscle stretch. J Anat. 2006 Apr;208(4):459-70.

[176] Nozawa H, Chiu C, Hanahan D. Infiltrating neutrophils mediate the initial angiogenic switch in a mouse model of multistage carcinogenesis. Proc Natl Acad Sci U S A. 2006 Aug 15;103(33):12493-8.

[177] Di Nicola M, Carlo-Stella C, Magni M, Milanesi M, Longoni PD, Matteucci P, et al. Human bone marrow stromal cells suppress T-lymphocyte proliferation induced by cellular or nonspecific mitogenic stimuli. Blood. 2002 May 15;99(10):3838-43.

[178] Sato K, Ozaki K, Oh I, Meguro A, Hatanaka K, Nagai T, et al. Nitric oxide plays a critical role in suppression of T-cell proliferation by mesenchymal stem cells. Blood. 2007 Jan 1;109(1):228-34.

[179] Bettelli E, Carrier Y, Gao W, Korn T, Strom TB, Oukka M, et al. Reciprocal developmental pathways for the generation of pathogenic effector $\mathrm{TH} 17$ and regulatory T cells. Nature. 2006 May 11;441(7090):235-8.

[180] Hori S, Nomura T, Sakaguchi S. Control of regulatory T cell development by the transcription factor Foxp3. Science. 2003 Feb 14;299(5609):1057-61.

[181] Khattri R, Cox T, Yasayko SA, Ramsdell F. An essential role for Scurfin in CD4+CD25+ T regulatory cells. Nat Immunol. 2003 Apr;4(4):337-42.

[182] Brunkow ME, Jeffery EW, Hjerrild KA, Paeper B, Clark LB, Yasayko SA, et al. Disruption of a new forkhead/winged-helix protein, scurfin, results in the fatal lymphoproliferative disorder of the scurfy mouse. Nat Genet. 2001 Jan;27(1):68-73.

[183] van der Vliet HJ, Nieuwenhuis EE. IPEX as a result of mutations in FOXP3. Clin Dev Immunol. 2007;2007:89017.

[184] Shevach EM, Thornton A, Suri-Payer E. T lymphocyte-mediated control of autoimmunity. Novartis Found Symp. 1998;215:200-11; discussion 11-30.

[185] Collison LW, Workman CJ, Kuo TT, Boyd K, Wang Y, Vignali KM, et al. The inhibitory cytokine IL-35 contributes to regulatory T-cell function. Nature. $2007 \mathrm{Nov}$ 22;450(7169):566-9.

[186] Bluestone JA, Abbas AK. Natural versus adaptive regulatory T cells. Nat Rev Immunol. 2003 Mar;3(3):253-7. 
[187] Chen W, Jin W, Hardegen N, Lei KJ, Li L, Marinos N, et al. Conversion of peripheral CD4+CD25- naive $\mathrm{T}$ cells to CD4+CD25+ regulatory $\mathrm{T}$ cells by TGF-beta induction of transcription factor Foxp3. J Exp Med. 2003 Dec 15;198(12):1875-86.

[188] Tarbell KV, Yamazaki S, Olson K, Toy P, Steinman RM. CD25+ CD4+ T cells, expanded with dendritic cells presenting a single autoantigenic peptide, suppress autoimmune diabetes. J Exp Med. 2004 Jun 7;199(11):1467-77.

[189] Madec AM, Mallone R, Afonso G, Abou Mrad E, Mesnier A, Eljaafari A, et al. Mesenchymal stem cells protect NOD mice from diabetes by inducing regulatory $T$ cells. Diabetologia. 2009 Jul;52(7):1391-9.

[190] Feng G, Wood KJ, Bushell A. Interferon-gamma conditioning ex vivo generates CD25+CD62L+Foxp3+ regulatory $\mathrm{T}$ cells that prevent allograft rejection: potential avenues for cellular therapy. Transplantation. 2008 Aug 27;86(4):578-89.

[191] Markees TG, Phillips NE, Gordon EJ, Noelle RJ, Shultz LD, Mordes JP, et al. Long-term survival of skin allografts induced by donor splenocytes and anti-CD154 antibody in thymectomized mice requires CD4(+) T cells, interferon-gamma, and CTLA4. J Clin Invest. 1998 Jun 1;101(11):2446-55.

[192] Feng G, Gao W, Strom TB, Oukka M, Francis RS, Wood KJ, et al. Exogenous IFN-gamma ex vivo shapes the alloreactive T-cell repertoire by inhibition of Th17 responses and generation of functional Foxp3+ regulatory T cells. Eur J Immunol. 2008 Sep;38(9):2512-27.

[193] Sawitzki B, Kingsley CI, Oliveira V, Karim M, Herber M, Wood KJ. IFN-gamma production by alloantigen-reactive regulatory $\mathrm{T}$ cells is important for their regulatory function in vivo. J Exp Med. 2005 Jun 20;201(12):1925-35.

[194] Thornton AM, Shevach EM. CD4+CD25+ immunoregulatory T cells suppress polyclonal $\mathrm{T}$ cell activation in vitro by inhibiting interleukin 2 production. $\mathrm{J}$ Exp Med. 1998 Jul 20;188(2):287-96.

[195] Tai X, Cowan M, Feigenbaum L, Singer A. CD28 costimulation of developing thymocytes induces Foxp3 expression and regulatory $\mathrm{T}$ cell differentiation independently of interleukin 2. Nat Immunol. 2005 Feb;6(2):152-62.

[196] Sageshima J, Ciancio G, Chen L, Burke GW. Anti-interleukin-2 receptor antibodies-basiliximab and daclizumab-for the prevention of acute rejection in renal transplantation. Biologics. 2009;3:319-36.

[197] Kretschmer K, Apostolou I, Hawiger D, Khazaie K, Nussenzweig MC, von Boehmer $\mathrm{H}$. Inducing and expanding regulatory $\mathrm{T}$ cell populations by foreign antigen. Nat Immunol. 2005 Dec;6(12):1219-27. 
[198] Semedo P, Correa MC, Cenedeze MA, Malheiros DMA, Shimizu MH, Seguro AC, et al. Mesenchymal Stem Cells attenuate renal fibrosis through immune modulation and remodelling properties in a rat remnant model. Stem Cells. 2009;Accept for publication.

[199] Eder W, von Mutius E. Hygiene hypothesis and endotoxin: what is the evidence? Curr Opin Allergy Clin Immunol. 2004 Apr;4(2):113-7.

[200] Cua DJ, Sherlock J, Chen Y, Murphy CA, Joyce B, Seymour B, et al. Interleukin23 rather than interleukin-12 is the critical cytokine for autoimmune inflammation of the brain. Nature. 2003 Feb 13;421(6924):744-8.

[201] Park H, Li Z, Yang XO, Chang SH, Nurieva R, Wang YH, et al. A distinct lineage of CD4 T cells regulates tissue inflammation by producing interleukin 17. Nat Immunol. 2005 Nov;6(11):1133-41.

[202] Harrington LE, Hatton RD, Mangan PR, Turner H, Murphy TL, Murphy KM, et al. Interleukin 17-producing CD4+ effector $T$ cells develop via a lineage distinct from the $T$ helper type 1 and 2 lineages. Nat Immunol. 2005 Nov;6(11):1123-32.

[203] Mangan PR, Harrington LE, O'Quinn DB, Helms WS, Bullard DC, Elson CO, et al. Transforming growth factor-beta induces development of the $\mathrm{T}(\mathrm{H}) 17$ lineage. Nature. 2006 May 11;441(7090):231-4.

[204] Klassen HJ, Imfeld KL, Kirov, II, Tai L, Gage FH, Young MJ, et al. Expression of cytokines by multipotent neural progenitor cells. Cytokine. 2003 May;22(3-4):101-6.

[205] Raffaghello L, Bianchi G, Bertolotto M, Montecucco F, Busca A, Dallegri F, et al. Human mesenchymal stem cells inhibit neutrophil apoptosis: a model for neutrophil preservation in the bone marrow niche. Stem Cells. 2008 Jan;26(1):151-62.

[206] Ye P, Rodriguez FH, Kanaly S, Stocking KL, Schurr J, Schwarzenberger P, et al. Requirement of interleukin 17 receptor signaling for lung CXC chemokine and granulocyte colony-stimulating factor expression, neutrophil recruitment, and host defense. J Exp Med. 2001 Aug 20;194(4):519-27.

[207] Zhang ZG, He QY, Liu XM, Tang XY, Chen LZ. [Effect of Interleukin-17 on neutrophil apoptosis]. Beijing Da Xue Xue Bao. 2006 Jun 18;38(3):305-9.

[208] English K, Barry FP, Mahon BP. Murine mesenchymal stem cells suppress dendritic cell migration, maturation and antigen presentation. Immunol Lett. 2008 Jan 15;115(1):50-8.

[209] Kerkis I, Ambrosio CE, Kerkis A, Martins DS, Zucconi E, Fonseca SA, et al. Early transplantation of human immature dental pulp stem cells from baby teeth to golden retriever muscular dystrophy (GRMD) dogs: Local or systemic? J Transl Med. 2008;6:35. 